\title{
Of Course It's Always the End of Time
}

Pliny reads while Vesuvius chokes Pompeii. Phaethon crashes the sun. The sea gulps Atlantis. The Melian women are sold.

Woodsmoke-and-Glorious, Some day things will still. The catherine wheels of beaded spokes clip-clopping over curbs. Rose and saffron crowns kiss the icon face, beneath the bamboo canopy, in the funeral procession for Time, which was good. String the cans and let them clatter. Soap the windows; write it big. The end will not be frayed, nor will it stink of untended meats. It will pattern as consummation of hot wax and water: burning leaves, amoeba glyphs, asymmetrical stars. We'll sit on the porch then. Shelled bugs in the eaves will walk. The backyard dogs and bloated goldfish will Lazarus-up. Bread cast upon dark waters, dark asphalt, will return in algal bloom as being.

No need to be afraid. My grandmother's hands net flocks of southerly birds and shake. Smaller birds, or Mexican jumping beans, flit in her lips. If beans: then heel-toe, hop-step. If birds: then titlarks from landscapes of live-in-sky. They haunt the brain, the rafters; then take the palms, the knuckles; then flap you, quill-bones, away. She hears the pan banging from the other side. She hears them calling Red Rover, Red Rover. At the garage sale we lay her sateen nightgowns on the lawn. They smell of the skin she bosomed us in. We price each bundt pan, the LBJ biographies and Old West paperbacks.

Woodsmoke-and-Glorious, You heard about Billy the Kid. For Rome to rise, Carthage must fall. The worm eats Gilgamesh's brother. Babylonians wreck the temple and the merry-hearted sigh. It rains and floods. In Florence, in plague, revelers let their homes go, as they let their bodies go, knowing no tomorrow. President Jackson tells the Cherokee to walk eight hundred miles.

On tender filaments this cloak hangs. Woodsmoke-and-Glorious, At the Alzheimer's house, the old professor tried to pay for din- 
ner every night. Canned peaches, potpie; his gracious decorum. He unclasped his coin purse, doing what he'd always done. All one day he told me, I have my best things on. I have all my best things on. I said, Yes, Everett, you have your best things on. And I said, Ladies, doesn't Everett look handsome? And we all agreed: that cardigan, that tie. At night, with the terrors crowding, helping him to bed, I saw that he did have all his best things on. Seven pressed shirts, buttoned and tucked, one over the next.

One day we'll slough the husk of such-and-such. Pick the burrs from our heels. We'll put on the homespun linen of our shining hours. A cadenza will begin. It won't be coy trills or triplets. There will come discordant double-stops, like birth pangs, like trains, then the sustained and shapely whole note that is home. We'll move there; we'll thrum.

Woodsmoke-and-Glorious, When our neighbor began to go, her scalp shone blue and she lit her bed like a bulb. Her friends helped count contractions in this labor she did not want. All processes move toward homeostasis, save birth, sex, and death, which move toward sweat. My great-grandmother told the checkout lady when she was ready to die. The checkout lady told her to pray on it. She went a few weeks later, perhaps she wore her gloves.

Viaticum is traveling food; some take it for the way. Some lip the salt of their lover's goodnight kiss. We do not want the ones we love to leave. The world grows baggy and ill-fitting. They die while we step out for a smoke; this tether loosed, their steed apace.

Lisbon quakes. The Spaniards empty Hispaniola of the Arawak. A woman named Vera bakes in the New Orleans sun. Giant Elk are gone.

Woodsmoke-and-Glorious, A coffee cup can work like a pearly nautilus, so once I heard the sea's words. Matchstick girl waves her carbon arms and calls, How he kissed me under the Moorish Wall. How he brings me into the banquet hall. Static, a gull. Then the source from the sea says, I am coming. And the matchstick sundered on the far bank groan, Even so, come. 